\title{
OPTIMIZATION OF HOT-AIR AND MICROWAVE DRYING PROCESS PARAMETERS FOR EVALUATION OF PHENOLICS AND ANTIOXIDANT ACTIVITY IN SLICED WHITE BUTTON MUSHROOM (Agaricus bisporus) USING RESPONSE SURFACE METHODOLOGY
}

\begin{tabular}{|c|c|}
\hline $\begin{array}{r}{ }^{1} \text { Bolu Abant Izzet } \\
\text { https://doi.org/10.343 }\end{array}$ & $\begin{array}{l}\text { versity, Faculty of Engineering, Food Engineering Department, } \\
\text { mpus of Golkoy14030 Bolu,Turkey } \\
₫ \text { deryaatalay@ibu.edu.tr } \\
2021.13 .1 .3\end{array}$ \\
\hline Article history: & ABSTRACT \\
\hline $\begin{array}{l}\text { Received: } \\
\text { 18 May } 2020 \\
\text { Accepted: } \\
\quad 15 \text { February } 2021\end{array}$ & $\begin{array}{l}\text { This study was conducted to investigate hot-air and microwave dryings on } \\
\text { phenolics and antioxidant activity of dried white button mushroom slices } \\
\text { (Agaricus bisporus) using the response surface methodology. It was also } \\
\text { aimed to determine optimized drying conditions. In hot-air drying, total }\end{array}$ \\
\hline $\begin{array}{l}\text { Keywords: } \\
\text { Antioxidant Activity; } \\
\text { Drying; } \\
\text { Microwave; } \\
\text { Phenolic Compounds; } \\
\text { White Button Mushroom. }\end{array}$ & $\begin{array}{l}\text { phenolics content reduced with corresponding increase in drying } \\
\text { temperature and slice thickness, whereas in microwave drying, the total } \\
\text { phenolics content increased with microwave power. Although the effect of } \\
\text { drying temperature on antioxidant activity is not significant, there is a } \\
\text { decrease in antioxidant activity as the slice thickness of the samples } \\
\text { increases. Microwave power had also a significant linear effect on } \\
\text { antioxidant activity of dried samples }(\mathrm{p}<0.01 \text { ). Both increases and decreases } \\
\text { in individual phenolic compounds were detected with the change of drying } \\
\text { conditions and sample thickness. A quadratic model was well fitted to all } \\
\text { responses. As a result of numerical optimization, optimum conditions for } \\
\text { hot-air drier and microwave oven were suggested as } 50{ }^{\circ} \mathrm{C} \text { and } 600 \text { Watt } \\
\text { having mushroom slices of } 2 \text { mm thickness, respectively. Our results show } \\
\text { that the quality of dried mushroom depends on the drying method and } \\
\text { conditions. Also, microwave drying is suitable method for drying of } \\
\text { mushroom slices within a shorter time compared with hot-air drying. }\end{array}$ \\
\hline
\end{tabular}

\section{Introduction}

Mushrooms have been widely consumed by humans for centuries in many countries for their characteristic delicate flavor and taste (Giri and Prasad, 2007; Celen et al., 2010). Besides, they are rich in carbohydrates, proteins, fibers, vitamins, minerals, unsaturated fatty acids. Mushrooms are recognized as an important source of biologically active compounds. So, they have several beneficial activities like antibacterial, antifungal, antioxidant, antitumor, antiallergic, antiatherogenic and antiinflammatory (Manzi et al., 2001; Giri and Prasad, 2007; Vaz et al., 2010; Argyropoulos et al., 2011; Kalac, 2013). They are also an excellent source of biologically active compounds such as polyphenolics classified as free radical inhibitors (Choi et al., 2006; Heleno et al., 2010; Yahia et al., 2017). The main phenolics are known as gallic acid, pyrogallol, protocatechuic acid, naringin and myricetin in edible mushrooms such as Agaricus bisporus, Pleurotus ostreatus, Flammulina velutipes, Pleurotus eryngii, and Lentinus edodes (Kim et al., 2008).

It is reported that there are more than 38000 mushroom varieties in nature, but only 22 of them are produced and one of the most popular varieties is known as white button mushroom called Agaricus bisporus. This variety 
contributes about $40 \%$ of the total World production (Manzi et al., 2001; Walde et al., 2006; Giri and Prasad, 2007). According to Food and Agricultural Organization (FAO), world production of mushrooms exceeds ten million tons in 2017. The production of cultivated mushrooms in Turkey is around 40.000 tons in the year of 2017 (FAOSTAT, 2019).

Since mushrooms contain high level of moisture (ranging from 85.2 to $94.7 \%$ ) and activity of enzymes, they deteriorate rapidly after harvest (Giri and Prasad, 2007; Manzi et al., 1999; Manzi et al., 2004). For this reason, mushrooms are suggested to be consumed or preserved immediately (Giri and Prasad, 2007). Drying is one of the important preservation methods by reducing the moisture content to a level for safe storage (Giri and Prasad, 2007; Argyropoulos et al., 2011). Conventional hot air drying is a simple and practical method, but it requires more energy and long-time (Argyropoulos et al., 2011). Since microwave drying has some advantages such as increased drying rate, maintenance of nutritional value, color and original flavor, it has been proposed as a rapid and efficient drying alternative to conventional hot air drying (Maskan, 2001; Giri and Prasad, 2007; Askari et al., 2009; ValadezCarmona et al., 2017).

To improve quality and yield of dried product, optimization study could be used in industrial process. Response surface methodology (RSM) is a statistical procedure widely used for effect of process parameters and determination of process optimization (Erbay and Icier, 2009; Šumić et al., 2017). Current study was carried out with the aim to use RSM for the optimization of drying parameters including both hot-air drying temperature/slice thickness and microwave power/slice thickness on white button mushroom (Agaricus bisporus).

In this research, it is aimed that effects of hot-air and microwave dryings on bioactive properties such as total phenolic content, antioxidant activity and individual phenolic compounds of mushrooms with 2-6 $\mathrm{mm}$ thickness. Different hot-air temperatures $\left(50^{\circ}\right.$, $60^{\circ}$ and $\left.70^{\circ} \mathrm{C}\right)$ and microwave powers $(90,345$ and $600 \mathrm{~W})$ were performed to compare bioactive properties. There are researchers about changes in total phenolics (Bhattacharya et al., 2014; Radzki et al., 2014; Šumić et al., 2017) but any research was found related with the variation of individual phenolics during drying of mushrooms. The objective of this study is also to determine optimum process conditions for drying of mushroom slices by using response surface methodology.

\section{Material and methods}

\subsection{Material}

Freshly harvested white button mushrooms Agaricus bisporus were provided from a private company in Bolu, Turkey. The samples immediately were washed and stored at $+4^{\circ} \mathrm{C}$ until drying process. Mushroom slices were obtained by cutting mushrooms vertically using a hand operated food slicer. The thickness of mushroom slices had been used as 2, 4 and 6 $\mathrm{mm}$. They were immediately weighed and dried at hot-air drier and microwave oven. The initial moisture content of the fresh mushrooms was $91.44 \%$. Drying experiments were carried out with two replicates. Analyses were performed in duplicate.

\subsection{Drying}

\section{i) Hot-air drying}

The sliced mushrooms were dried at hot-air temperature of $50^{\circ}, 60^{\circ}$ and $70{ }^{\circ} \mathrm{C}$ with air flow rate of $1.5 \mathrm{~m} / \mathrm{s}$ using a hot-air drier designed and fabricated in Eksis Industrial Drying Systems, Isparta, Turkey. Slices were spread in a single layer on the tray which was placed into the drier. The samples were dried till the moisture content was reduced to 8-10\%. Drying times were 5, 3.5 and 2.5 hours at applied temperatures, respectively.

\section{ii) Microwave drying}

Microwave drying of the sliced mushrooms was performed with microwave oven (BoschHMT84G421, P.R.C) with maximum output of $900 \mathrm{~W}$ at $2450 \mathrm{MHz}$. Sliced samples were dried at different microwave powers $(90,345$ and $600 \mathrm{~W})$. Slices were placed in a single layer on the rotating table. The samples were dried till the 
moisture content was reduced to 8-10\%. Slices (samples) were dried at applied microwave powers for 90,35 and 15 minutes, respectively.

\subsection{Modelling drying data (Response Surface Methodology)}

The results were analyzed by response surface methodology (RSM) using the software Statease Inc. 9.1 (Minneapolis, ABD). The experimental design employed was a Central Composite Design for two independent variables each at three levels. The drying variables of temperature $\left({ }^{\circ} \mathrm{C}\right)$ and slice thickness $(\mathrm{mm})$ for hot-air drying; microwave power (W) and slice thickness $(\mathrm{mm})$ for microwave drying were studied using RSM. In this study, 12 experiments were created for each drying type according to a two-level factorial design with center and star points (Table 1).

Table 1. Levels of hot-air and microwave drying process variables

\begin{tabular}{|l|c|c|c|c|}
\hline & & \multicolumn{3}{|c|}{ Factor Levels } \\
\hline $\begin{array}{l}\text { Independent variable } \\
\text { for hot-air drying } \\
\text { (Units) }\end{array}$ & Symbol & $\mathbf{- 1}$ & $\mathbf{0}$ & $\mathbf{+ 1}$ \\
\hline Temperature $\left({ }^{\circ} \mathrm{C}\right)$ & $\beta_{1}$ & 50 & 60 & 70 \\
\hline Slice thickness (mm) & $\beta_{2}$ & 2 & 4 & 6 \\
\hline $\begin{array}{l}\text { Independent variable } \\
\text { for microwave } \\
\text { drying (Units) }\end{array}$ & Symbol & $\mathbf{- 1}$ & $\mathbf{0}$ & $+\mathbf{1}$ \\
\hline $\begin{array}{l}\text { Microwave power } \\
\text { (Watt) }\end{array}$ & $\beta 1$ & 90 & 345 & 600 \\
\hline Slice thickness (mm) & $\beta 2$ & 2 & 4 & 6 \\
\hline
\end{tabular}

Quadratic model proposed for response is shown in Equation 1:

$$
\mathrm{Y}=\beta_{0}+\sum_{\mathrm{i}=1}^{\mathrm{n}} \beta_{\mathrm{i}} \mathrm{X}_{\mathrm{i}}+\sum_{\mathrm{i}=1}^{\mathrm{n}} \beta_{\mathrm{ii}} \mathrm{X}_{\mathrm{i}}^{2}+\sum_{\mathrm{i}<\mathrm{J}}^{\mathrm{n}} \beta_{\mathrm{ij}} \mathrm{X}_{\mathrm{i}} \mathrm{X}_{\mathrm{j}} \quad \ldots \text { Eq. (1) }
$$

$\beta_{0}$ is the constant coefficient, $\beta_{\mathrm{i}}$ is the linear coefficient, $\beta_{\mathrm{ii}}$ is the quadratic coefficient, $\beta_{\mathrm{ij}}$ is the cross product coefficient and $\mathrm{x}_{\mathrm{i}}$ and $\mathrm{x}_{\mathrm{j}}$ are independent variables.

Desired goals (maximization of total phenolics content and antioxidant activity) were used to perform optimization of variables and the response.

\subsection{Methods \\ Moisture analysis}

Moisture analysis was performed at $105{ }^{\circ} \mathrm{C}$ (AOAC, 1990). Samples were analyzed in duplicate and average moisture content was recorded.

\section{Chemicals}

ABTS (3-ethylbenzothiazoline-6-sulfonic acid), Trolox (6-hydroxy-2,5,7,8tetramethychroman-2 carboxylic acid), pyrogallol, t-cinnamic acid, caffeic acid, pcoumaric acid and $(+)$-catechin were obtained from Sigma Aldrich (Sigma-Aldrich, Inc., Saint Louis, USA). Folin-Ciocalteu reagent, sodium carbonate, ethanol and the other HPLC grade solvents were purchased from Merck (Darmstadt, Germany).

\section{Extraction}

Extraction of samples was performed with methanol using the method of Thaipong et al. (2006), with some modifications. 3 grams of dried and milled mushrooms were mixed with $25 \mathrm{~mL}$ methanol and homogenized with ultra turrax (IKA, Germany). This solution was kept at $4{ }^{\circ} \mathrm{C}$ for $12 \mathrm{~h}$ and then centrifuged at $9000 \mathrm{rpm}$ for 25 min with a centrifuge (Nuve, Ankara, Turkey). The supernatant was transferred to a 25 $\mathrm{mL}$ volumetric flask, brought to volume with methanol and stored at $-20{ }^{\circ} \mathrm{C}$ until analysis.

\section{Analysis of total phenolics content}

The amount of total phenolics was detected by using a modified Folin-Ciocalteu reagent colorimetric method (Shahidi et al., 2001). The absorbance of all samples was read at $720 \mathrm{~nm}$ using a UV/VIS spectrophotometer (Shimadzu, Kyoto, Japan). The content of total phenolics in dried mushroom samples were determined using a standard curve prepared with $(+)$-catechin (10$150 \mathrm{mg} / \mathrm{L})$ and expressed as (+)-catechin equivalents ( $\mathrm{mg} / \mathrm{g}$ dry matter).

\section{Analysis of antioxidant activity (TEAC)}

Trolox equivalent antioxidant capacity (TEAC) method was used to determine antioxidant activity of samples (Re et al., 1999). 
$15 \mu \mathrm{L}$ of dried mushroom extract was added to $1 \mathrm{~mL}$ of diluted ABTS*+ solution; the mixture was mixed and the absorbance was recorded. The absence of ABTS*+ was determined by measuring the decrease of absorbance at $734 \mathrm{~nm}$ for 6 min. Results were analyzed by reference to the Trolox and expressed as micromolar Trolox equivalent antioxidant capacity $(\mu \mathrm{M}$ Trolox/100g dry matter).

\section{Determination of individual phenolic compounds with HPLC}

Phenolic compounds were separated on a Perkin Elmer C 18 column $(5 \mu \mathrm{m}, 250$ x $4.6 \mathrm{~mm}$ i.d.) according to method described by Biswas et al. (2013). The column was operated at a temperature of $25^{\circ} \mathrm{C}$. A Shimadzu HPLC pump and PDA detector (Prominence LC-20A, Shimadzu, Kyoto, Japan) were used. Phenolic compounds were detected at $280 \mathrm{~nm}$ (pyrogallol, $(+)$-catechin and t-cinnamic acid) and $320 \mathrm{~nm}$ (caffeic acid and p-coumaric acid) with a flow rate of $0.8 \mathrm{~mL} / \mathrm{min}$. Separations were carried out by varying the proportion of $2.5 \%(\mathrm{v} / \mathrm{v})$ acetic acid in water (mobile phase A) and $70 \%$ methanol in water (mobile phase B). The solvent gradient elution program was as follows: $10 \%$ to $26 \% \mathrm{~B} \mathrm{(v/v)} \mathrm{in} 10 \mathrm{~min}$, to $70 \% \mathrm{~B}$ at $20 \mathrm{~min}$ and to $90 \% \mathrm{~B}$ at 25 to $31 \mathrm{~min}$, finally to $10 \% \mathrm{~B}$ at 39 to $45 \mathrm{~min}$. The injection volume for all samples and standards was $10 \mu \mathrm{L}$. Identification of phenolics was carried out by comparison of the HPLC retention times with corresponding standards of pyrogallol (7.8 min), (+)-catechin (17.9 min), caffeic acid (21.7 min), p-coumaric acid (24.8 $\mathrm{min})$ and t-cinnamic acid (30.4 $\mathrm{min})$ (Figure 1). The concentrations were calculated, using the standard calibration curves of pyrogallol $(30-150 \mathrm{mg} / \mathrm{L}),(+)$-catechin $(5-25$ $\mathrm{mg} / \mathrm{L})$, caffeic acid $(1-10 \mathrm{mg} / \mathrm{L})$, p-coumaric acid $(0.5-2.5 \mathrm{mg} / \mathrm{L})$ and $\mathrm{t}$-cinnamic acid $(1-10$ $\mathrm{mg} / \mathrm{L})$. The sample extracts were filtered through a $0.45 \mu \mathrm{m}$ pore size syringe filter before HPLC analysis.

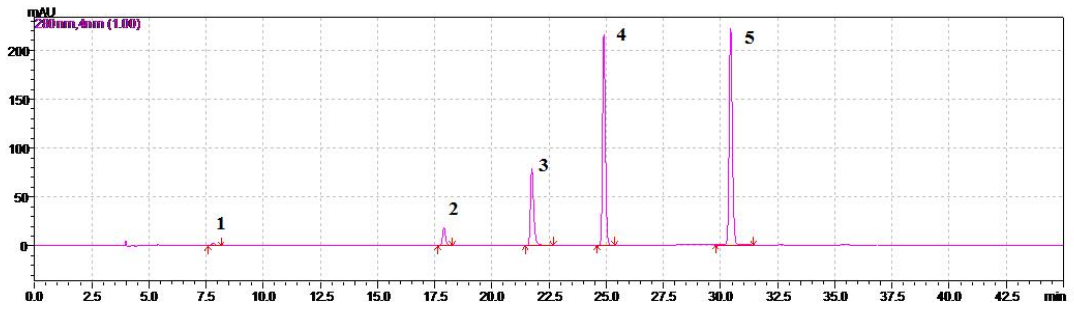

Figure 1. HPLC chromatogram of phenolic standards. Identified compounds 1, Pyrogallol; 2, (+)catechin; 3 , caffeic acid; 4, $p$-coumaric acid and 5, $t$-cinnamic acid

\section{Results and discussions}

\subsection{Total phenolics content}

\section{Effect of hot-air drying conditions}

Total phenolics content of fresh white button mushroom was $9.28 \mathrm{mg} / \mathrm{g}$ d.m. and this parameter ranged from $1.06 \mathrm{mg} / \mathrm{g}$ d.m. to 2.14 $\mathrm{mg} / \mathrm{g}$ d.m. in samples after dried at hot-air (Table 2). The change in total phenolics was best described by the quadratic model $\left(\mathrm{p}<0.01 ; \mathrm{R}^{2}\right.$ : $0.967)$. Drying temperature and slice thickness had negative significant linear effects on total phenolics content of dried white button mushroom $(\mathrm{p}<0.01)($ Table 3$)$. Total phenolics content reduced with corresponding increase in drying temperature and slice thickness. Total phenolics content decreased to $1.61 \mathrm{mg} / \mathrm{g} \mathrm{d}$.m. from $2.14 \mathrm{mg} / \mathrm{g}$ d.m. when the slice thickness increased to $6 \mathrm{~mm}$ from $2 \mathrm{~mm}$ at $50{ }^{\circ} \mathrm{C}$ (Figure 2). This data exhibits thinner mushroom samples showed higher total phenolics than thicker samples. Because, thicker samples dried longer than the thinner samples, so long drying time caused a higher loss of total phenolics. Table 2 also shows that the rise in temperature from $50^{\circ}$ to $70{ }^{\circ} \mathrm{C}$ led to decline of total phenolics content of dried samples with the same slice thickness from $2.03 \mathrm{mg} / \mathrm{g}$ d.m. to $1.12 \mathrm{mg} / \mathrm{g}$ d.m. 
Table 2. Central composite design with the observed responses for total phenolic content (TPC), antioxidant activity (AA) and content of individual phenolic compounds of hot-air and microwave dried white button mushrooms

\begin{tabular}{|c|c|c|c|c|c|c|c|c|c|c|}
\hline & Run & $\begin{array}{c}\text { Temp. }\left({ }^{\circ} \mathrm{C}\right) / \\
\text { Mic. Power }(\mathbf{W})\end{array}$ & $\begin{array}{l}\text { Slice thick. } \\
\quad(\mathbf{m m})\end{array}$ & $\begin{array}{c}\text { TPC } \\
\text { (mg/g d.m.) }\end{array}$ & $\begin{array}{c}\text { AA } \\
(\mu \mathrm{mol} \\
\text { Trolox } / \mathbf{1 0 0} \mathrm{g} \\
\text { d.m. })\end{array}$ & $\begin{array}{c}\text { Pyrogallol } \\
\text { (mg/kg d.m.) }\end{array}$ & $\begin{array}{l}\text { (+)-Catechin } \\
\text { (mg/kg d.m.) }\end{array}$ & $\begin{array}{c}t \text {-Cinnamic } \\
\text { acid } \\
\text { (mg/kg d.m.) }\end{array}$ & $\begin{array}{c}\text { Caffeic acid } \\
\text { (mg/kg d.m.) }\end{array}$ & $\begin{array}{c}p \text {-Coumaric } \\
\text { acid } \\
\text { (mg/kg d.m.) }\end{array}$ \\
\hline \multirow{12}{*}{ 竞 } & 1 & $70(+1)$ & $2(-1)$ & 1.18 & 13.65 & 702.89 & 56.19 & 4.96 & 0.82 & 4.52 \\
\hline & 2 & $70(+1)$ & $4(0)$ & 1.12 & 9.3 & 870.05 & 52.93 & 6.51 & 0.61 & 2.65 \\
\hline & 3 & $60(0)$ & $4(0)$ & 1.4 & 9.3 & 647.73 & 79.58 & 12.82 & 0.51 & 3.21 \\
\hline & 4 & $70(+1)$ & $6(+1)$ & 1.06 & 10.81 & 929.09 & 46.29 & 6.61 & 0.54 & 2.09 \\
\hline & 5 & $50(-1)$ & $6(+1)$ & 1.61 & 11.76 & 843.48 & 57.26 & 7.71 & 0.33 & 4.29 \\
\hline & 6 & $50(-1)$ & $2(-1)$ & 2.14 & 15.74 & 333.28 & 81.94 & 9.19 & 0.85 & 4.21 \\
\hline & 7 & $60(0)$ & $2(-1)$ & 1.52 & 11.25 & 380.66 & 67.5 & 8.08 & 0.77 & 2.88 \\
\hline & 8 & $60(0)$ & $4(0)$ & 1.26 & 9.87 & 635.04 & 79.93 & 12.15 & 0.64 & 2.74 \\
\hline & 9 & $60(0)$ & $6(+1)$ & 1.3 & 11.08 & 963.13 & 67.53 & 12.29 & 0.68 & 3.1 \\
\hline & 10 & $60(0)$ & $4(0)$ & 1.35 & 10.16 & 832.63 & 85.12 & 10.04 & 0.59 & 2.51 \\
\hline & 11 & $60(0)$ & $4(0)$ & 1.28 & 10.39 & 714.3 & 88.05 & 12.55 & 0.43 & 2.86 \\
\hline & 12 & $50(-1)$ & $4(0)$ & 2.03 & 10 & 534.47 & 65.15 & 7.29 & 0.41 & 3.2 \\
\hline \multirow{12}{*}{ 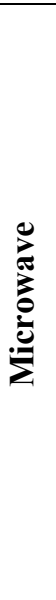 } & 1 & $345(0)$ & $4(0)$ & 1.11 & 7.94 & 345.21 & 26.41 & 0.29 & 0.19 & 1.01 \\
\hline & 2 & $600(+1)$ & $6(+1)$ & 1.96 & 12.71 & 361.44 & 21.34 & 0.39 & 0.16 & 0.67 \\
\hline & 3 & $600(+1)$ & $4(0)$ & 2.01 & 10.71 & 375.65 & 19.27 & 0.42 & 0.15 & 0.79 \\
\hline & 4 & $345(0)$ & $2(-1)$ & 1.39 & 12.18 & 312.11 & 39.17 & 0.41 & 0.24 & 2.02 \\
\hline & 5 & $345(0)$ & $4(0)$ & 1.47 & 12.29 & 403.14 & 26.92 & 0.4 & 0.14 & 0.97 \\
\hline & 6 & $600(+1)$ & $2(-1)$ & 2.83 & 12.75 & 267.97 & 38.41 & 0.5 & 0.24 & 1.33 \\
\hline & 7 & $90(-1)$ & $2(-1)$ & 1.08 & 9.2 & 1359.3 & 35.3 & 5.15 & 0.13 & 1.19 \\
\hline & 8 & $345(0)$ & $4(0)$ & 1.17 & 10.4 & 352.68 & 24.63 & 0.38 & 0.13 & 1.07 \\
\hline & 9 & $90(-1)$ & $6(+1)$ & 1.21 & 8.41 & 992.43 & 31.21 & 10.74 & 0.14 & 0.51 \\
\hline & 10 & $345(0)$ & $4(0)$ & 1.2 & 11.33 & 304.05 & 23.84 & 0.39 & 0.14 & 0.83 \\
\hline & 11 & $345(0)$ & $6(+1)$ & 2.36 & 13.61 & 379.77 & 32.68 & 0.43 & 0.15 & 0.69 \\
\hline & 12 & $90(-1)$ & $4(0)$ & 0.87 & 4.96 & 1040.24 & 32.52 & 5.58 & 0.09 & 0.81 \\
\hline
\end{tabular}


Table 3. Analysis of variance of regression coefficients of the fitted quadratic model equations for the variations of the total phenolics content (TPC), antioxidant activity (AA) and content of individual phenolic compounds of hot-air and microwave dried white button mushrooms

\begin{tabular}{|c|c|c|c|c|c|c|c|c|}
\hline & Coefficient & TPC & $\mathbf{A A}$ & Pyrogallol & $(+)$-Catechin & $\begin{array}{c}t \text {-Cinnamic } \\
\text { acid } \\
\end{array}$ & $\begin{array}{c}\text { Caffeic } \\
\text { acid }\end{array}$ & $\begin{array}{c}p \text {-Coumaric } \\
\text { acid }\end{array}$ \\
\hline \multirow{11}{*}{ } & $\beta_{0}$ (intercept) & 1.35 & 9.58 & 701.52 & 80.33 & 11.57 & 0.55 & 2.71 \\
\hline & Linear & & & & & & & \\
\hline & $\beta_{1}$ (temp.) & $-0.4^{* *}$ & -0.6233 & $+131.80^{* *}$ & $-8.16^{*}$ & -1.02 & +0.063 & -0.41 \\
\hline & $\beta_{2}$ (slice thick.) & $-0.14^{* *}$ & $-1.165^{*}$ & $+219.81^{* *}$ & -5.76 & +0.73 & $-0.15^{*}$ & -0.36 \\
\hline & Quadratic & & & & & & & \\
\hline & $\beta_{11}$ & $+0.17^{*}$ & +0.7725 & +12.56 & $-15.61^{*}$ & $-4.03^{* *}$ & -0.061 & +0.44 \\
\hline & $\beta_{22}$ & +0.003 & $+2.2875^{*}$ & -17.80 & -7.14 & -0.74 & +0.15 & +0.51 \\
\hline & Cross product & & & & & & & \\
\hline & $\beta_{12}$ & $+0.1^{*}$ & +0.285 & -71 & +3.7 & +0.78 & +0.06 & $-0.63^{*}$ \\
\hline & $\mathrm{R}^{2}$ & 0.967 & 0.812 & 0.903 & 0.831 & 0.829 & 0.786 & 0.801 \\
\hline & $\begin{array}{l}\text { Model } \\
(\mathrm{p}>\text { F value })\end{array}$ & $<0.01$ & $<0.05$ & $<0.01$ & $<0.05$ & $<0.05$ & $<0.05$ & $<0.05$ \\
\hline \multirow{11}{*}{ 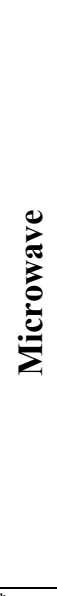 } & $\beta_{0}$ (intercept) & 1.29 & 10.402 & 344.16 & 26.25 & 0.17 & 0.15 & 1.01 \\
\hline & Linear & & & & & & & \\
\hline & $\beta_{1}$ (mic. power) & $+0.606^{* *}$ & $+2.267^{* *}$ & $-397.82^{* *}$ & $-3.34^{*}$ & $-3.37^{* *}$ & $+0.032^{*}$ & +0.047 \\
\hline & $\beta_{2}$ (slice thick.) & +0.038 & +0.1 & -34.29 & $-4.61^{*}$ & +0.91 & $-0.027^{*}$ & $-0.45^{* *}$ \\
\hline & Quadratic & & & & & & & \\
\hline & $\beta_{11}$ & +0.05 & $-2.3913^{*}$ & $+378.01^{* *}$ & -1.96 & $+3.21^{* *}$ & -0.029 & $-0.30^{*}$ \\
\hline & $\beta_{22}$ & +0.485 & $+2.6688^{*}$ & +16.01 & $+8.07^{* *}$ & +0.63 & $+0.046^{*}$ & +0.26 \\
\hline & Cross product & & & & & & & \\
\hline & $\beta_{12}$ & -0.25 & +0.1875 & $+115.09^{*}$ & -3.24 & $-1.41^{*}$ & -0.022 & +0.005 \\
\hline & $\mathrm{R}^{2}$ & 0.813 & 0.815 & 0.978 & 0.873 & 0.958 & 0.852 & 0.868 \\
\hline & $\begin{array}{l}\text { Model } \\
\text { ( } p>F \text { value) }\end{array}$ & $<0.05$ & $<0.05$ & $<0.01$ & $<0.05$ & $<0.01$ & $<0.05$ & $<0.05$ \\
\hline
\end{tabular}

${ }^{* *}$ Significant at $\mathrm{p}<0.01 ;{ }^{*}$ Significant at $\mathrm{p}<0.05$

The loss of total phenolics in this present study is in agreement with results obtained by other researchers who studied dried Centella asiatica (Niamnuy et al., 2013), sour cherry (Wojdylo et al., 2014) and chanterelle mushroom (Šumić et al., 2017). Wojdylo et al. (2014) indicated that phenolic compounds can be damaged by increasing temperature and a long exposing to high temperatures. In this study, combined effect of drying temperature and slice thickness also significantly reduced total phenolics of dried white button mushroom $(p<0.05)$.

\section{Effect of microwave drying conditions}

Total phenolics content of white button mushroom dried at microwave showed significant decreases $(0.87-2.83 \mathrm{mg} / \mathrm{g}$ d.m.) compared with fresh sample $(9.28 \mathrm{mg} / \mathrm{g}$ d.m.). The change in total phenolics content of white button mushroom dried with microwave showed a good fit to a quadratic model $\left(\mathrm{p}<0.05 ; \mathrm{R}^{2}\right.$ : 0.813 ). Table 2 presents total phenolics of the samples dried at twelve drying conditions. Total phenolic was highest $(2.83 \mathrm{mg} / \mathrm{g} \mathrm{d}$.m. $)$ in the sample dried at a power of $600 \mathrm{~W}$, with $2 \mathrm{~mm}$ thickness. The lowest total phenolics was found in the sample dried at $90 \mathrm{~W}$, with $4 \mathrm{~mm}$ thickness $(0.87 \mathrm{mg} / \mathrm{g}$ d.m.). Microwave power had a significant positive linear effect on total phenolics content of dried white button mushroom $(p<0.01)$ (Table 3$)$. On the other hand, the statistical analysis indicated that the 
effect of slice thickness and interaction among parameters were insignificant ( $\mathrm{p}>0.05$ ).

Total phenolics significantly increased with the increase in the microwave power (Figure 2). Total phenolics increased to $2.83 \mathrm{mg} / \mathrm{g} \mathrm{d} . \mathrm{m}$. from $1.08 \mathrm{mg} / \mathrm{g}$ d.m. when the microwave power increased to $600 \mathrm{~W}$ from $90 \mathrm{~W}$ at the same thickness value (Figure 2). This result is consistent with the other studies related with Thai red curry powder (Inchuen et al., 2010) and dried sage plants (Sellami et al., 2013). Another research about extraction of phenolic compounds in dried mushrooms by using oven and microwave, total phenolics increased with microwave power (Celebi Sezer et al., 2017). Al Juhaimi et al. (2018) also investigated the effect of microwave $(360 \mathrm{~W}, 540 \mathrm{~W}$ and $720 \mathrm{~W})$ oven
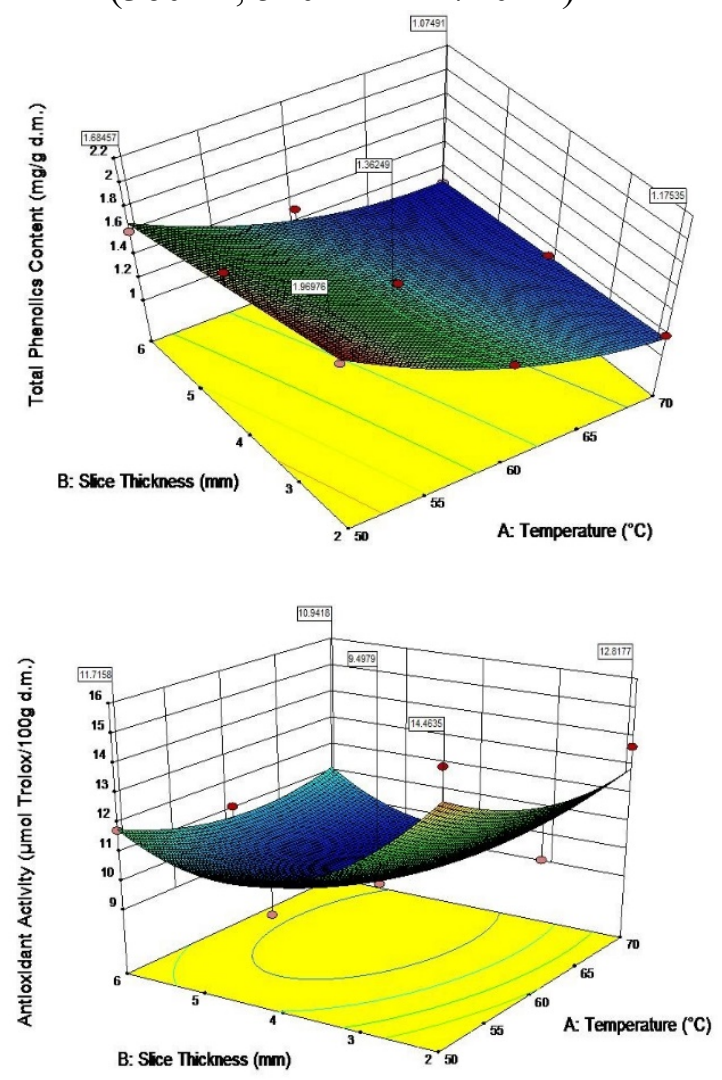

roasting on oil yields, phenolic compounds, antioxidant activity and fatty acid composition of some apricot kernels. According to that study, total phenolics and antioxidant activities of kernels increased at 360 and $540 \mathrm{~W}$, while those parameters decreased at $720 \mathrm{~W}$.

In this research, the increment in total phenolics according to the intense of microwave can be explained by the effect of microwave treatment in releasing phenolic compounds. It is reported that plant cell wall polymers can deteriorate when intense heat formed from the microwaves leads a high vapor pressure and temperature in the tissue. So, cell wall phenolics or bond phenolics could be released and more phenolics could be extracted (Inchuen et al., 2010; Sellami et al., 2013).
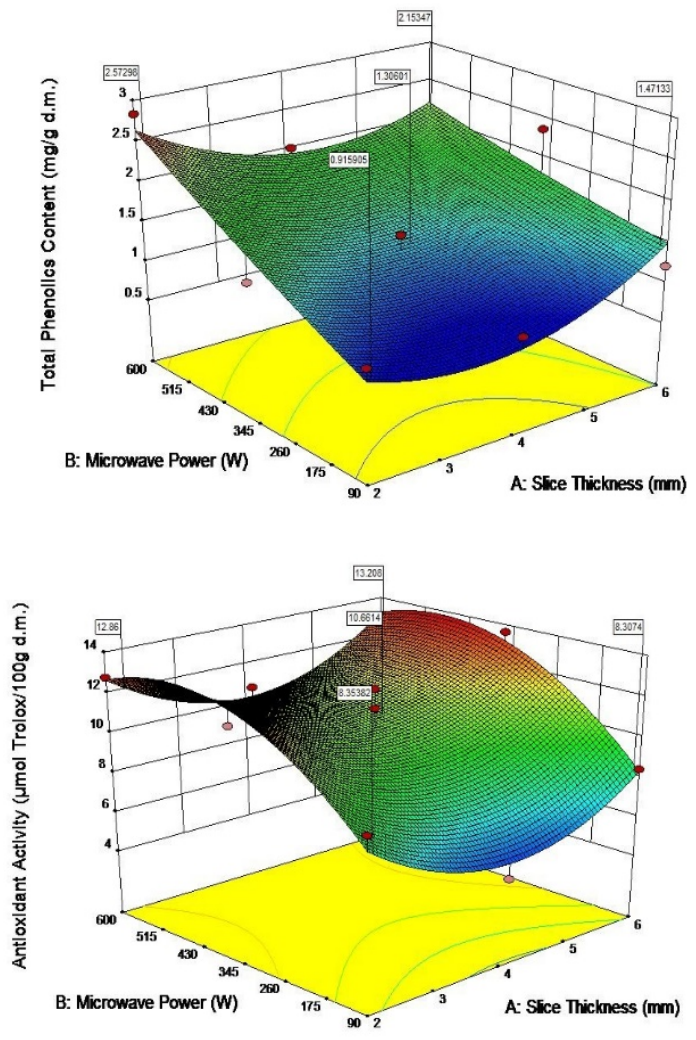

Figure 2. Response surface plot showing effect of different drying parameters on total phenolics content and antioxidant activity

\subsection{Antioxidant activity}

\section{Effect of hot-air drying conditions}

Hot-air drying process led to decrease in antioxidant activity of fresh white button mushrooms. The observed antioxidant activity of fresh sample $(23.59 \mu \mathrm{moL}$ Trolox $/ 100 \mathrm{~g} \mathrm{~d}$.m. $)$ was found in the range of 9.3-15.74 $\mu \mathrm{moL}$ Trolox/100g d.m. after hot air drying (Table 2). A quadratic model $\left(\mathrm{p}<0.05 ; \mathrm{R}^{2}: 0.812\right)$ was also determined for the variation of antioxidant 
activity of white button mushroom dried with hot-air. Linear and quadratic effects of slice thickness on antioxidant activity of dried white button mushroom were found significant $(p<0.05)$. Slice thickness had a negative impact on antioxidant activity. A decrease in the antioxidant activity was observed as the slice thickness was increased. Antioxidant activity decreased to $11.76 \mu \mathrm{mol}$ Trolox $/ 100 \mathrm{~g}$ d.m. from $15.74 \mu \mathrm{mol}$ Trolox $/ 100 \mathrm{~g}$ d.m. when the slice thickness increased to $6 \mathrm{~mm}$ from $2 \mathrm{~mm}$ at $50^{\circ} \mathrm{C}$ (Figure 2). Our findings are consistent with the other studies which asparagus (Nindo et al., 2003) and sour cherry (Wojdylo et al., 2014) dried at hot-air. The decrease in antioxidant activity of hot-air dried mushroom in this study can be attributed to the decrease in total phenolics in hot-air dried samples. Moreover, thicker samples exposure to temperatures longer than the other samples during drying. So, bioactive compounds degrade more in thicker samples. A better-quality product with higher scavenging activity was obtained in banana slices with lesser thickness values are also reported by Khawas et al. 2016.

In this study, the effects of temperature and the interaction between drying temperature and slice thickness on antioxidant activity were found insignificant $(\mathrm{p}>0.05)$.

\section{Effect of microwave drying conditions}

The antioxidant activity of mushroom dried at microwave ranged from $4.96 \mu \mathrm{mol}$ Trolox $/ 100 \mathrm{~g}$ d.m. to $13.61 \mu \mathrm{mol}$ Trolox $/ 100 \mathrm{~g}$ d.m. (Table 2). The variation in antioxidant activity of white button mushroom dried with microwave oven was best explained by the quadratic model $\left(\mathrm{p}<0.05, \mathrm{R}^{2}\right.$ : 0.815). Quadratic effects of slice thickness and microwave power were determined significant $(p<0.05)$. Microwave power had also a significant linear effect on antioxidant activity of dried white button mushroom $(p<0.01)$. An increase in the antioxidant activity was observed as the microwave power increased. As can be observed in Figure 2, rising microwave power from $90 \mathrm{~W}$ to $600 \mathrm{~W}$ promoted antioxidant activity significantly $(\mathrm{p}<0.01)$. Antioxidant activity increased to $12.75 \mu \mathrm{mol}$ Trolox $/ 100 \mathrm{~g}$ d.m. from $9.2 \mu \mathrm{mol}$ Trolox $/ 100 \mathrm{~g}$ d.m. when the microwave power increased to $600 \mathrm{~W}$ from $90 \mathrm{~W}$ at $2 \mathrm{~mm}$ (Figure 2). This increment could be explained that the deterioration of plant tissue increased with a rise in the power of microwave, causing more phenolic compounds to be released. So antioxidant activity increases (Inchuen et al., 2010). Similar results observed compared to the other studies related with dried asparagus (Nindo et al., 2003), strawberry (Wojdylo et al., 2009), Thai red curry powder (Inchuen et al., 2010) and sour cherry (Wojdylo et al., 2014). Those studies reported that antioxidant activity increased in proportional to the microwave power.

The results showed slice thickness had significant adverse effect on antioxidant activity $(p<0.05)$. Antioxidant activity exhibited a negative relationship with slice thickness. As slice thickness declined, higher antioxidant activity was observed compared to thicker samples, which can be caused by much longer drying time needed. The antioxidant activity of white button mushroom with $4 \mathrm{~mm}$ thickness dried at $600 \mathrm{~W}$ was $10.71 \mu \mathrm{mol}$ Trolox/100g d.m., while this value was raised to $12.75 \mu \mathrm{mol}$ Trolox $/ 100 \mathrm{~g}$ d.m. in dried mushroom with $2 \mathrm{~mm}$ thickness at the same microwave power.

\subsection{Phenolic Compounds \\ Effect of hot-air drying conditions}

Pyrogallol (324.1 mg/kg d.m.), (+)-catechin (3.23 mg/kg d.m.), t-cinnamic acid $(9.53 \mathrm{mg} / \mathrm{kg}$ d.m.), caffeic acid (3.39 mg/kg d.m.) and pcoumaric acid $(0.69 \mathrm{mg} / \mathrm{kg} \quad$ d.m. $)$ were determined in fresh white button mushroom and pyrogallol was found to be the most abundant compound. When fresh sample was subjected to hot-air drying, increases in pyrogallol, (+)catechin and p-coumaric acid were observed and the contents of these phenolics were obtained in the ranges of $333-963 \mathrm{mg} / \mathrm{kg}$ d.m., 46.3-88.1 $\mathrm{mg} / \mathrm{kg}$ d.m. and 2.1-4.5 $\mathrm{mg} / \mathrm{kg}$ d.m., respectively. On the other hand, caffeic acid declined in the range of $0.33-0.85 \mathrm{mg} / \mathrm{kg} \mathrm{d} . \mathrm{m}$. Increases in t-cinnamic acid were only observed in samples dried at $60{ }^{\circ} \mathrm{C}$, while at the other 
drying temperatures t-cinnamic acid tended to be decrease. Representative HPLC chromatograms (280 and $320 \mathrm{~nm}$ ) of a sample (4 mm slice thickness) dried at $50{ }^{\circ} \mathrm{C}$ is depicted in Figure 3.

The quadratic model was found to obey for the variation of pyrogallol $\left(\mathrm{p}<0.01 ; \mathrm{R}^{2}\right.$ : 0.903$)$, $(+)$-catechin $\left(\mathrm{p}<0.05 ; \mathrm{R}^{2}: 0.831\right)$, t-cinnamic acid $\left(\mathrm{p}<0.05 ; \mathrm{R}^{2}: 0.829\right)$, caffeic acid $(\mathrm{p}<0.05$; $\mathrm{R}^{2}$ : 0.786$)$ and $\mathrm{p}$-coumaric acid $\left(\mathrm{p}<0.05 ; \mathrm{R}^{2}\right.$ : 0.801 ) contents of white button mushroom dried with hot-air. Pyrogallol was significantly affected by the linear term of temperature and slice thickness (Table 3 ). A significant increase was observed for the pyrogallol content of dried white button mushroom with the increase of drying temperature and slice thickness $(\mathrm{p}<0.01)$. Increase in hot-air temperature from $50^{\circ}$ to 70 ${ }^{\circ} \mathrm{C}$ at a fixed thickness value $(2 \mathrm{~mm})$ enhanced the pyrogallol content about 2-fold (Table 2). The results showed t-cinnamic acid was the only phenolic acid which significantly affected by the quadratic term of temperature $(p<0.01)$. It was observed t-cinnamic acid increased with the temperature up to $60{ }^{\circ} \mathrm{C}$. No significant linear effects of drying temperature and slice thickness on t-cinnamic acid and p-coumaric acid contents were observed ( $p>0.05)$ (Table 3$)$. However, the linear effect of the interaction between drying temperature and slice thickness on p-coumaric acid was found significant $(\mathrm{p}<0.05)$. A decrease in the p-coumaric acid content was observed as the drying temperature and slice thickness were increased. The $(+)$-catechin content was found to be decreased with increasing temperature $(\mathrm{p}<0.05)$. The effect of cabinet drying at 50,60, 70 and $80{ }^{\circ} \mathrm{C}$ on the content of phenolics especially catechins in apple pomace have been recently reported by Heras-Ramírez et al. (2012) and they found that the losses associated with catechin can be attributed to the epimerization reactions at higher drying temperatures. The results also revealed that slice thickness had adverse effect on caffeic acid content $(p<0.05)$.

Similar results observed compared to the other studies in dried apricot (Igual et al. 2012), sage plants (Sellami et al., 2013) and sour cherry (Wojdylo et al., 2014). Wojdylo et al. 2014, also found a decrease in some phenolics ((-)epicatechin, p-coumaric acid, chlorogenic acid etc.) and an increase in (+)-catechin with increasing temperature during convective drying. Valadez-Carmona et al. 2017 also reported that drying process affect the release of phenolic compounds from fruits and vegetables positively, negatively and neutral because of microstructural changes.

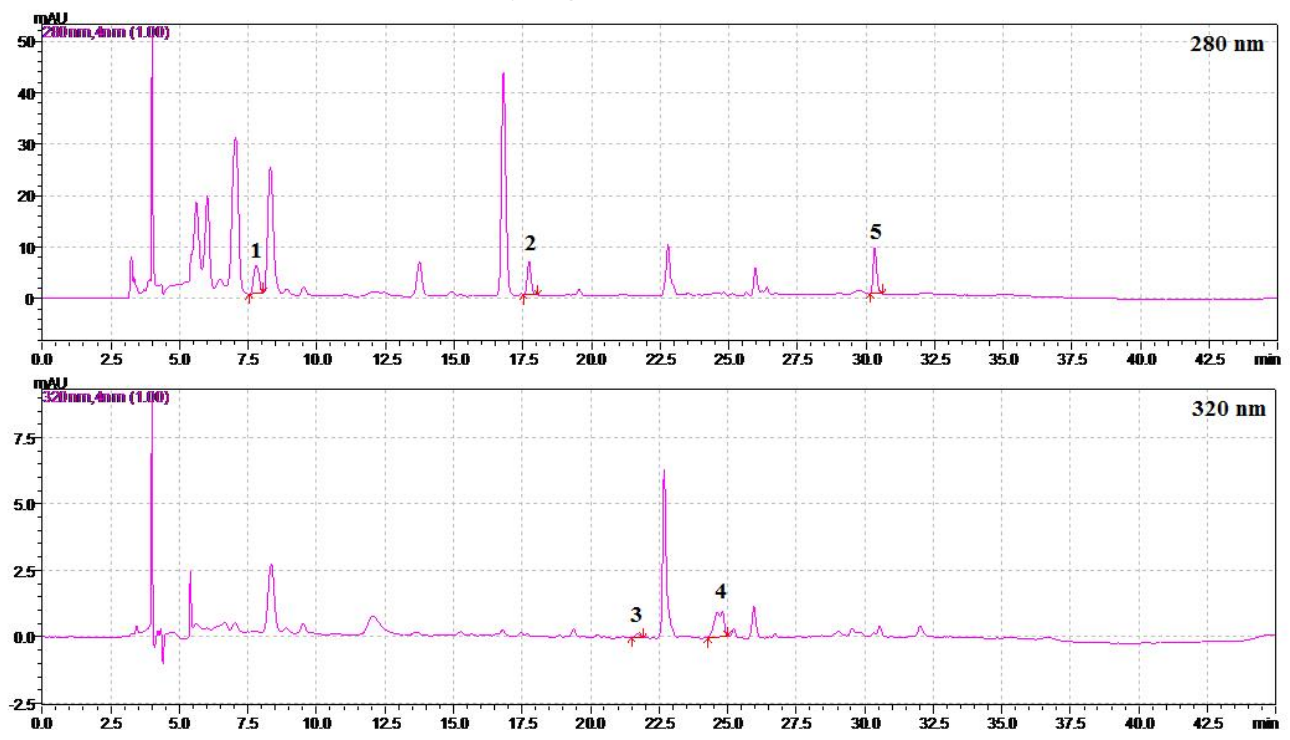

Figure 3. The HPLC chromatograms of phenolic compounds in white button mushrooms dried at 50 ${ }^{\circ} \mathrm{C}, 4 \mathrm{~mm}$ with hot-air drier. Identified compounds 1, Pyrogallol; 2, (+)-catechin; 3, caffeic acid; 4, $p$-coumaric acid and 5, $t$-cinnamic acid 


\section{Effect of microwave drying conditions}

Pyrogallol (324.1 mg/kg d.m.), (+)-catechin (3.23 mg/kg d.m.), t-cinnamic acid $(9.53 \mathrm{mg} / \mathrm{kg}$ d.m.), caffeic acid (3.39 mg/kg d.m.) and pcoumaric acid $(0.69 \mathrm{mg} / \mathrm{kg}$ d.m.) contents of fresh white button mushroom were determined in the ranges of $268-1359 \mathrm{mg} / \mathrm{kg}$ d.m., 19.3-39.2 $\mathrm{mg} / \mathrm{kg}$ d.m., $0.29-10.74 \mathrm{mg} / \mathrm{kg}$ d.m., 0.09-0.24 $\mathrm{mg} / \mathrm{kg} \quad$ d.m. and $0.51-2.02 \quad \mathrm{mg} / \mathrm{kg} \quad$ d.m., respectively, when microwave drying was applied. It is relevant that $(+)$-catechin content enhanced about 10-13 fold; whereas caffeic acid declined 14-35 fold. This result revealed that microwave affected the phenolics differently.

Response surface methodology was also performed for exhibiting the effects of microwave power and slice thickness on phenolic compounds of white button mushroom dried with microwave oven. Data fitted to a quadratic model for the variation of pyrogallol $\left(\mathrm{p}<0.01 ; \mathrm{R}^{2}: 0.978\right),(+)$-catechin $\left(\mathrm{p}<0.05 ; \mathrm{R}^{2}\right.$ : $0.873)$, t-cinnamic acid $\left(\mathrm{p}<0.01 ; \mathrm{R}^{2}: 0.958\right)$, caffeic acid $\left(\mathrm{p}<0.05 ; \mathrm{R}^{2}: 0.852\right)$ and $\mathrm{p}$-coumaric acid $\left(\mathrm{p}<0.05 ; \mathrm{R}^{2}: 0.868\right)$ (Table 3$)$.

The linear effects of microwave power and slice thickness were found significant for $(+)$ catechin and caffeic acid $(\mathrm{p}<0.05)$. The $(+)-$ catechin and caffeic acid were found to be decreased with increasing slice thickness. An adverse significant effect of microwave power on $(+)$-catechin, leading the $(+)$-catechin decreased with the increase of microwave power except for the sample with the slice thickness of $2 \mathrm{~mm}$. On the other hand, it was determined that increase in the caffeic acid was observed as the microwave power enhanced. The linear and quadratic effects of microwave power were determined significant upon a decrease in pyrogallol and $t$-cinnamic acid $(p<0.01)$. The linear effect of slice thickness $(p<0.01)$ and quadratic effect of microwave power $(\mathrm{p}<0.05)$ were observed significant for $\mathrm{p}$-coumaric acid. The p-coumaric acid decreased as the slice thickness increased. The combined effect of microwave power and slice thickness significantly reduced pyrogallol and t-cinnamic acid contents of dried white button mushrooms $(\mathrm{p}<0.05)$.
Similar results observed compared to the other studies in dried strawberry (Wojdylo et al., 2009), sage plants (Sellami et al., 2013) and sour cherry (Wojdylo et al., 2014). The study by Wojdylo et al. (2009) indicated that variation in the phenolic compounds of Kent and Elsanta strawberry cultivars during microwave drying attributed to the higher microwave power. This research indicated that p-coumaroyl, ellagic acid, quercetin and (+)-catechin contents of Kent cultivar increased with increasing microwave power. Ellagic acid and (+)-catechin contents of Elsanta cultivar also increased by increasing microwave power. On the other hand, it was reported to be a decrease in p-coumaroyl as the microwave power increased.

\section{Conclusions}

By using quadratic models fitted in this study, total phenolics content, antioxidant activity and phenolic compounds of white button mushroom dried with hot-air drier and microwave oven can be predicted. The optimum conditions for maximum total phenolics content and antioxidant activity in drying of white button mushrooms in hot-air drier and microwave oven corresponded to temperature of $50{ }^{\circ} \mathrm{C}$ at $2 \mathrm{~mm}$ and microwave power of 600 Watt at $2 \mathrm{~mm}$, respectively. In this study, microwave drying is suggested as suitable method than hot-air drying because of least reducing the content of bioactive compounds and antioxidant activity and reducing drying time.

\section{References}

A.L. Juhaimi, F., Özcan, M.M., Ghafoor, K., Babiker, E.E. (2018). The effect of microwave roasting on bioactive compounds, antioxidant activity and fatty acid composition of apricot kernel and oils. Food Chemistry, 243, 414-9.

AOAC. (1990). Official Methods of Analysis of the AOAC. Association of Official Analysis Chemists, Washington DC.

Argyropoulos, D., Heindl, A., Müller, J. (2011). Assessment of convection, hot air combined with microwave-vacuum and freeze-drying 
methods for mushrooms with regard to product quality. International Journal of Food Science and Technology, 46, 333-42.

Askari, G.R., Emam-Djomeh, Z., Mousavi, S.M. (2009). An investigation of the effects of drying methods and conditions on drying characteristics and quality attributes of agricultural products during hot air and hot air/ microwave-assisted dehydration. Drying Technology, 27, 831-41.

Bhattacharya, M., Srivastav, P.P., Mishra, H.N. (2014). Optimization of microwaveconvective drying of Oyster mushrooms (Pleurotus ostreatus) using responsesurface methodology. International Food Research Journal, 21(4), 1575-81.

Biswas, N., Balac, P., Narlakanti, S.K., Haque, M.D.E., Hassan, M.D.M. (2013). Identification of phenolic compounds in processed cranberries by HPLC method. Journal of Nutrition \& Food Sciences, 3, 181.

Celebi Sezer, Y., Sufer, O., Sezer, G. (2017). Extraction of phenolic compounds from oven and microwave dried mushrooms (Agaricus bisporus and Pleurotus ostreatus) by using methanol, ethanol and aceton as solvents. Indian Journal of Pharmaceutical Education and Research, 51(3), 393-7.

Celen, S., Kahveci, K., Akyol, U., Haksever, A. (2010). Drying behavior of cultured mushrooms. Journal of Food Processing and Preservation, 34, 27-42.

Choi, Y., Lee, S.M., Chun, J., Lee, H.B., Lee, J. (2006). Influence of heat treatment on the antioxidant activities and polyphenolic compounds of shiitake (Lentinus Edodes) mushroom. Food Chemistry, 99, 381-7.

Erbay, Z., Ic1er, F. (2009). Optimization of hot air drying of olive leaves using response surface methodology. Journal of Food Engineering, 91, 533-41.

FAOSTAT.http://www.fao.org/faostat/en/\#data /QC . FAOSTAT Online Database. 2019. Date accessed: 07.05.2019.

Giri, S.K., Prasad, S. (2007). Drying kinetics and rehydration characteristics of microwave-vacuum and convective hot air dried mushrooms. Journal of Food Engineering, 78, 512-21.

Heleno, S.A., Barros, L., Sousa, M.J., Martins, A., Ferreira, I.C.F.R. (2010). Tocopherols composition of Portuguese wild mushrooms with antioxidant capacity. Food Chemistry. 119, 1443-50.

Heras-Ramírez, M.E., Quintero-Ramos, A., Camacho-Dávila, A.A., Barnard, J., Talamás-Abbud, R., Torres-Muñoz, J.V., Salas-Muñoz, E. (2012). Effect of blanching and drying temperature on polyphenolic compound stability and antioxidant capacity of apple pomace. Food and Bioprocess Technology, 5, 2201-10.

Igual, M., Martinez, E.C., Esparza, M.E.M., Navarrete, N.M. (2012). Effect of processing on the drying kinetics and functional value of dried apricot. Food Research International, 47, 284-90.

Inchuen, S., Narkrugsa, W., Pornchaloempong, P. (2010). Effect of drying methods on chemical composition, color and antioxidant properties of Thai red curry powder. Natural Science, 44, 142-51.

Kalac, P. (2013). A review of chemical composition and nutritional value of wildgrowing and cultivated mushrooms. Journal of the Science of Food and Agriculture, 93, 209-18.

Khawas, P., Dash, K.K., Das, A.J. Deka, S.C. (2016). Modeling and optimization of the process parameters in vacuum drying of culinary banana (Musa ABB) slices by application of artificial neural network and genetic algorithm. Drying Technology, 34(4), 491-503.

Kim, M.Y., Seguin, P., Ahn, J.K., Kim, J.J., Chun, S.C., Kim, E.H., Park, Y.J., Ro, H.M., Chung, I.M. (2008). Phenolic compound concentration and antioxidant activities of edible and medicinal mushrooms from Korea. Journal of Agricultural and Food Chemistry, 56, 7265-70.

Manzi, P., Aguzzi, A., Pizzoferrato, L. (2001). Nutritional value of mushrooms widely consumed in Italy. Food Chemistry, 73, 3215. 
Manzi, P., Gambelli, L., Marconi, S., Vivanti, V., Pizzoferrato, L. (1999). Nutrients in edible mushrooms: an inter-species comparative study. Food Chemistry, 65, 477-82.

Manzi, P., Marconi, S., Aguzzi, A., Pizzoferrato, L. (2004). Commercial mushrooms: nutritional quality and effect of cooking. Food Chemistry, 84, 201-6.

Maskan, M. (2001). Drying, shrinkage and rehydration characteristics of kiwifruits during hot air and microwave drying. Journal of Food Engineering, 48, 177-82.

Niamnuy, C., Charoenchaitrakool, M., Mayachiew, P., Devahastin, S. (2013). Bioactive compounds and bioactivities of Centella asiatica (L.) urban prepared by different drying methods and conditions. Drying Technology, 31, 2007-15.

Nindo, C.I., Sun, T., Wang, S.W., Tang, J., Powers, J.R. (2003). Evaluation of drying technologies for retention of physical quality and antioxidants in asparagus (Asparagus officinalis, 1.). LWT- Food Science and Technology, 36, 507-16.

Radzki, W., Slawinska, A., Jablonska-Rys, E., Gustaw, W. (2014). Antioxidant capacity and polyphenolic content of dried wild edible mushrooms from Poland. International Journal of Medicinal Mushrooms, 16(1), 65-75.

Re, R., Pellegrini, N., Proteggente, A., Pannala, A., Yang, M., Rice-Evans, C. (1999). Antioxidant activity applying an improved ABTS radical cation decolorization assay. Free Radical Biology and Medicine, 26, 1231-37.

Sellami, I.H., Rahali, F.Z., Rebey, I.B., Bourgou, S., Limam, F., Marzouk, B. (2013). Total phenolics, flavonoids, and antioxidant activity of sage (Salvia officinalis 1.) plants as affected by different drying methods. Food Bioprocessing Technology, 6, 806-17.

Shahidi, F., Chavan, U.D., Naczk, M., Amarowicz, R. (2001). Nutrient distribution and phenolic antioxidants in air-classified fractions of beach pea (Lathyrus maritimus L.). Journal of Agricultural and Food Chemistry, 49, 926-33.

Šumić, Z., Tepić, A., Vidović, S., Vakula, A., Vladić, J. Pavlić, B. (2017). Process optimization of chanterelle (Cantharellus cibarlus) mushrooms vacuum drying. Journal of Food Processing and Preservation, 41, 1-12.

Thaipong, K., Boonprakob, U., Crosby, K., Cisneros-Zevallos, L., Byrne, D.H. (2006). Comparison of ABTS, DPPH, FRAP, and ORAC assays for estimating antioxidant activity from guava fruit extracts. Journal of Food Composition and Analysis, 19, 66975.

Valadez-Carmona, L., Plazola-Jacinto, C.P., Hernández-Ortega, M., Hernández-Navarro, M.D., Villarreal, F., NecoecheaMondragón, H., Ortiz-Moreno, A., Ceballos-Reyes, G. (2017). Effects of microwaves, hot air and freeze-drying on the phenolic compounds, antioxidant capacity, enzyme activity and microstructure of cacao pod husks (Theobroma cacao L.). Innovative Food Science and Emerging Technologies, 41, 378-86.

Vaz, J.A., Heleno, S.A., Martins, A., Almeida, G.M., Vasconcelos, M.H., Ferreira, I.C.F.R. (2010). Wild mushrooms Clitocybe alexandri and Lepista inversa: In vitro antioxidant activity and growth inhibition of human tumour cell lines. Food and Chemical Toxicology, 48, 2881-4.

Walde, S.G., Velu, V., Jyothirmayi, T., Math, R.G. (2006). Effects of pretreatments and drying methods on dehydration of mushroom. Journal of Food Engineering, 74, 108-15.

Wojdylo, A., Figiel, A., Lech, K., Nowicka, P., Oszmianski, J. (2014). Effect of convective and vacuum-microwave drying on the bioactive compounds, color and antioxidant capacity of sour cherries. Food Bioprocessing Technology, 7, 829-41.

Wojdylo, A., Figiel, A., Oszmianski, J. (2009). Effect of drying methods with the application of vacuum microwaves on the 
bioactive compounds, color, and antioxidant activity of strawberry fruits. Journal of Agricultural and Food Chemistry, 57, 133743.

Yahia, E.M., Gutiérrez-Orozco, F., MorenoPérez, M.A. (2017). Identification of phenolic compounds by liquid chromatography-mass spectrometry in seventeen species of wild mushrooms in Central Mexico and determination of their antioxidant activity and bioactive compounds. Food Chemistry, 226, 14-22.

\section{Acknowledgments}

This work was supported by research grant 2014.09.04.736 from Scientific Research Projects at Bolu Abant Izzet Baysal University. The authors also would like to thank Innovative Food Technologies Development Application and Research Centre (YENIGIDAM) for using HPLC. 